Vol. 2, No. 1, Juni 2021

\title{
SPEKTA
}

Jurnal Pengabdian Kepada Masyarakat : Teknologi dan Aplikasi

Journal homepage :

http://journal2.uad.ac.id/index.php/spekta

\section{PENERAPAN INTEGRATED FARMING SYSTEM (IFS) MENUJU DESA AGROWISATA DI DESA JATISARI, KECAMATAN JATISRONO, KABUPATEN WONOGIRI}

\author{
Srie Juli Rachmawatie ${ }^{1}$, Adib Norma Respati ${ }^{2 *}$, Nancy Oktyajati ${ }^{3}$, Libria Widiastuti ${ }^{1}$, \\ Endang Siti Rahayu ${ }^{4}$, Joko Sutrisno ${ }^{4}$ \\ ${ }^{1}$ Program Studi Agroteknologi, Universitas Islam Batik, Surakarta, Jawa Tengah, Indonesia \\ ${ }^{2}$ Program Studi Peternakan, Universitas Islam Batik, Surakarta, Jawa Tengah, Indonesia \\ ${ }^{3}$ Program Studi Teknik Industri, Universitas Islam Batik, Surakarta, Jawa Tengah, Indonesia \\ ${ }^{4}$ Program Studi Agribisnis, Universitas Sebelas Maret, Surakarta, Jawa Tengah, Indonesia
}

\begin{tabular}{l}
\hline ARTICLE INFO \\
\hline \\
Received : December, 2020 \\
Revised : January, 2021 \\
Accepted : April, 2021 \\
\hline
\end{tabular}

Keywords:

Integrated farming system;

entrepreneurship;

agriculture.

\begin{abstract}
Integrated Farming System is a management system for plants, livestock, and aquaculture with environment to produce an excellent product. The objectives of the community service activity were empowering Jatisari Village community to realize the Agrotourism Village, ensuring integrated farming systems run well and optimally, and making Jatisari Village a fostered village of the Faculty of Engineering, Science and Agriculture UNIBA. Integrated farming system is a system that combines agricultural activities, animal husbandry, fisheries, and forestry with other sciences related to agriculture in one land, so that it is expected to be one of the solutions for increasing land productivity, building programs and environmental conservation, and integrated village development. Entrepreneurship is also important to support the existence of agrotourism of Jatisari Village. Jatisari Village is prospective in developing agrotourism areas. Local potential, natural resources and human resources can be utilized to support the development of agrotourism areas.
\end{abstract}

\section{PENDAHULUAN}

Desa Jatisari adalah salah satu desa di Kecamatan Jatisrono yang memiliki potensi disektor pertanian. Sektor pertanian di Desa Jatisari terbagi dalam beberapa subsektor diantaranya subsektor peternakan, perikanan, tanaman pangan dan hortikultura, perkebunan, dan kehutanan. Beberapa jenis tanaman pertanian yang dikembangkan di Desa Jatisari antara lain tanaman padi, sayur-sayuran, jamur, porang, dan mete sebagai tanaman perkebunan yang utama dan budidaya lele. Pemanfaatan limbah juga telah dilakukan, namun belum memberikan hasil yang memuaskan bagi masyarakat Jatisari

\footnotetext{
* Corresponding author.

E-mail address: adibnorma@gmail.com

https://doi.org/10.12928/J.spekta.v2i1.3295
} 
Vol. 2, No. 1, Juni 2021

karena masih dalam taraf trial and error. Potensi yang ada di Desa Jatisari membuat pemerintah desa berniat untuk mengembangkan menjadi kawasan desa agrowisata. Desa Jatisari menjadi lokasi yang stretegis karena berada di persimpangan perbatasan Kabupaten Wonogiri, Kabupaten Karanganyar, dan Provinsi Jawa Timur. Penelitian Rachmawatie et al (2019) menunjukkan bahwa Desa Jatisari mempunyai potensi sumberdaya lokal yang baik untuk pengembangan sistem pertanian terpadu guna untuk meningkatkan pendapatan masyarakat. Berdasarkan aspek fisik dan ekonomi Desa Jatisari memiliki tingkat efisiensi baik. Kondisi calon kawasan agrowisata Desa Jatisari disajikan pada Gambar 1 dan gambar 2.

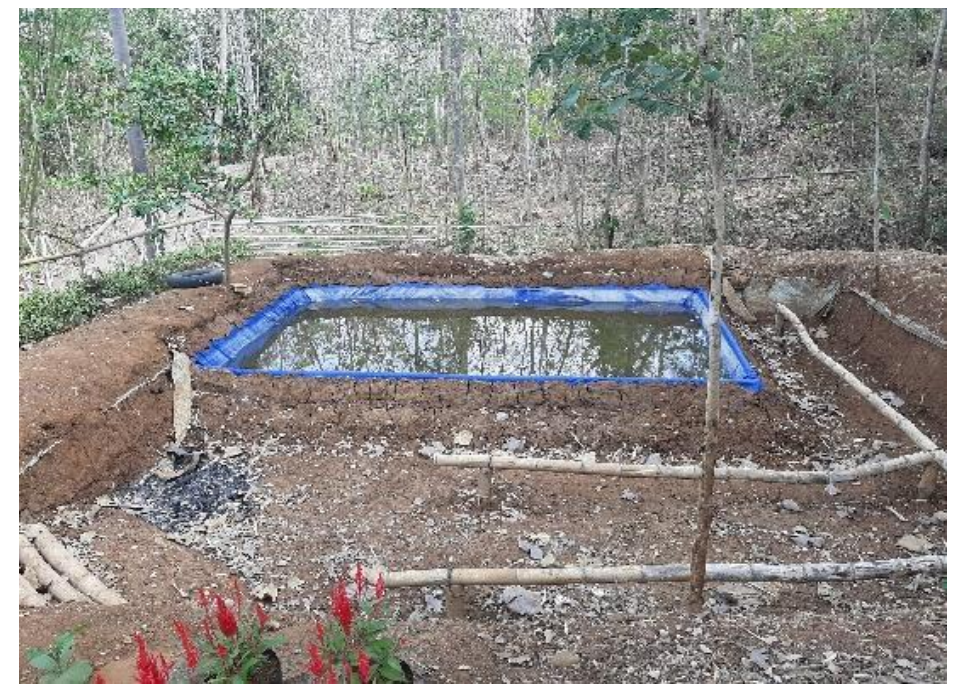

Gambar 1. Bekas kolam lele yang akan digunakan untuk pemancingan

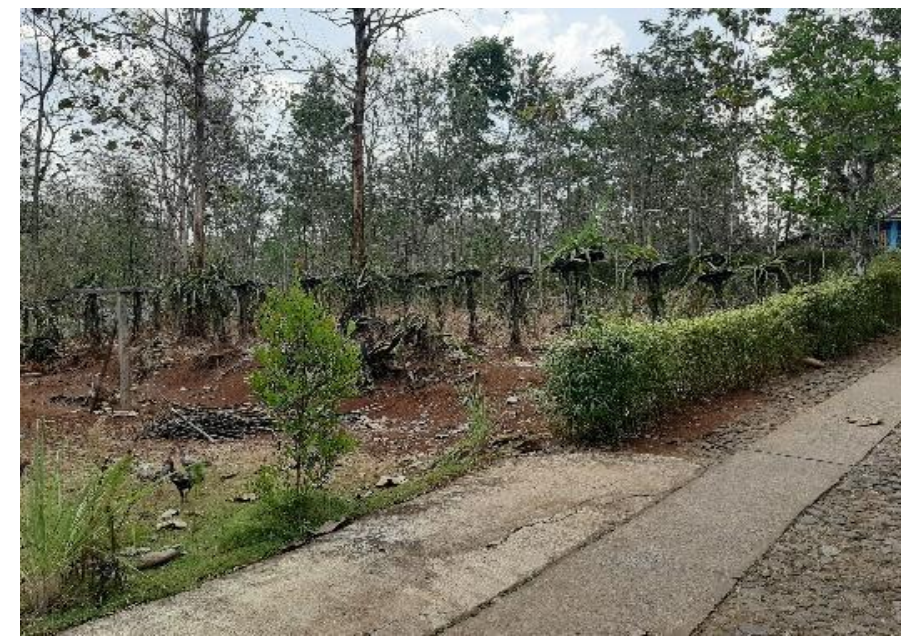

Gambar 2. Lahan yang akan ditanami porang

Konsep sistem pertanian terpadu diusung dalam pengembangan kawasan agrowisata ini. Integrated Farming System atau Sistem Pertanian Terpadu merupakan sebuah sistem yang mengelola usaha tani dengan memadukan sektor pertanian, peternakan maupun dengan kehutanan menjadi suatu kesatuan yang utuh (Nurcholis dan Supangkat, 2011). Dalam sistem pertanian terpadu seluruh potensi sumberdaya yang dimiliki masingmasing komponen usahatani dimanfaatkan secara optimal dengan prinsip zero waste, dengan kata lain tidak ada limbah atau hasil samping yang terbuang percuma (Abolla, et 
Vol. 2, No. 1, Juni 2021

al., 2018). Sistem Pertanian Terpadu akan memiliki dampak positif dan sesuai dengan kriteria pembangunan pertanian berkelanjutan,dikarenakan memiliki basis organik serta dikembangkan dengan basis potensi lokal (Nurcholis dan Supangkat, 2011). Simbolon et al (2017) menambahkan bahwa lahan yang digunakan secara berkelanjutan merupakan pemakaian lahan untuk memenuhi kebutuhan di masa sekarang, dan melestarikan sumberdaya untuk generasi selanjutnya di masa depan. Keuntungan dari sistem pertanian terpadu antara lain mengurangi konflik petani dengan peternak, mengurangi perambahan hutan, dapat meningkatkan pendapatan (Warintan et al., 2020), meningkatkan produktivitas lahan (Anam et al., 2010), memperbaiki ekologi (Rauf et al., 2013).

Sistem pertanian terpadu di Desa Jatisari apabila pengelolaannya dilakukan secara tepat maka dapat memberikan keuntungan bagi masyarakat. Faktor sosial budaya, ekonomi, kelembagaan, teknologi pertanian, dan kebijakan pemerintah merupakan kriteria yang dapat mempengaruhi keberhasilan dalam sistem pertanian berkelanjutan (Ma'ruf, 2017). Nurcholis dan Supangkat (2011) menambahkan bahwa tantangan dari suatu sistem pertanian terpadu atau berkelanjutan ialah untuk mendapatkan kombinasi antara tanaman, ternak serta input-input lain yang mengarah untuk mendapatkan produktivitas tinggi, keamanan produksi dan konservasi sumberdaya sebanding dengan kondisi lahan yang terbatas, jumlah tenaga kerja dan modal. Beberapa daerah di Indonesia telah melakukan pengembangan sistem pertanian terpadu,dimana dapat memberikan keuntungan ekonomi maupun lingkungan. Penelitian Ittaqillah et al (2020) menunjukkan bahwa sistem mina padi secara berkelanjutan membuat petani menjadi cukup partisipatif dalam melaksanakan dan memanfaatkan hasil dari mina padi. Hasil penelitian Siswati dan Nizar (2012) menunjukkan bahwa sistem pertanian terpadu kombinasi antara tanaman hortikultura dengan sapi mampu menambah pendapatan dari petani dan pemanfaatan lahan kosong menjadi lahan yang produktif. Ruhiyat et al. (2021) melakukan pemberdayaan masyarakat dalam penerapan integrated farming system (IFS) di Kampung Injeman, Desa Cibodas, Kecamatan Pasirjambu, Kabupaten Bandung. Dari kajian-kajian diatas, masih sedikit yang membahas secara khusus tentang integrated farming system (IFS) di Desa Agrowisata di Desa Jatisari, Kecamatan Jatisrono, Kabupaten Wonogiri.

Oleh karena itu, kegiatan pengabdian ini berupa penyuluhan dan pendampingan terhadap pelaksanaan sistem pertanian terpadu sebagai upaya memberdayakan masyarakat Desa Jatisari sehingga sistem pertanian terpadu dapat dilaksanakan dengan baik dan memberikan hasil yang optimal. Kegiatan ini memberikan pengetahuan baru ataupun melengkapi pengetahuan yang sudah dimiliki oleh masyarakat Desa Jatisari. Pengabdian kepada masyarakat ini diharapkan mampu meningkatkan partisipasi aktif masyarakat dalam mewujudkan kawasan Agrowisata Desa Jatisari sehingga sumber daya alam dapat dikelola dengan baik dengan sumber daya manusia yang tepat.

\section{METODE PELAKSANAAN}

Kegiatan pengabdian dilakukan di Desa Jatisari, Kecamatan Jatisrono, Kabupaten Wonogiri, Provinsi Jawa Tengah mulai bulan September sampai Oktober 2019 Metode pelaksanaan dalam kegiatan pengabdian adalah penyuluhan dan pendampingan masyarakat dalam mewujudkan kawasan agrowisata Desa Jatisari. Penyuluhan dilakukan dengan pemberian materi kepada masyarakat Desa Jatisari. Materi yang diberikan diantaranya mengenai Integrated Farming System (IFS) dan kewirausahaan. Peserta kegiatan pengabdian berjumlah 39 orang, dimana beberapa diantaranya merupakan 
Vol. 2, No. 1, Juni 2021

pelaku UMKM (Usaha Mikro, Kecil dan Menengah). Dilanjutkan dengan pendampingan yang berupa diskusi dengan pelaku UMKM untuk perbaikan pengelolaan usaha tani.

\section{HASIL DAN PEMBAHASAN}

Kegiatan pengabdian dilakukan dengan pemaparan materi oleh dua orang narasumber yang ahli di bidangnya. Pemaparan materi menganai penerapan Integrated Farming System (IFS) disampaikan oleh Prof. Dr. Hj. Endang Siti Rahayu, M.S.. Pemaparan meteri mengenai kewirausahaan disampaikan oleh Dr. Joko Sutrisno, M.P. Kedua narasumber merupakan dosen dari Fakultas Pertanian Universitas Sebelas Maret (UNS).

Pemaparan materi pertama dengan judul "Pemberdayaan Masyarakat dalam Upaya Penerapan Integrated Farming System (IFS) di Desa Jatisari, Jatisrono, Wonogiri". Sistem pertanian terpadu ialah sistem penggabungan dari sektor pertanian, peternakan, perikanan, kehutanan sertailmu lainnya, sehingga menjadi salah satu solusi untuk meningkatkan produktivitas lahan, konservasi lingkungan, serta pengembangan desa secara berkelanjutan. Desa Jatisari yang lahannya cenderung lahan kering membutuhkan penanganan dalam pengembangannya. Desa Jatisari memiliki potensi sumber daya manusia yang ulet, tidak mudah menyerah, dan pekerja keras. Kondisi lahan kering yang dimiliki digunakan untuk budidaya jamur, budidaya tanaman porang, dan peternakan ayam. Kotoran ayam dan sisa baglog jamur inilah yang digunakan sebagai pupuk organic untuk budidaya tanaman porang. Dwikoranto et al (2015) menyatakan penerapan konsep sistem pertanian terpadu dapat memperbaiki unsur hara dalam tanah. Salli et al (2019) menambahkan agroekosistem lahan kering dengan sistem pertanian terpadu dengan basis pisang tentunya dengan komponen lain yaitu ternak, jagung, sayur dan tanaman pakan ternak menggunakan pola tanam tumpang sari.

Pemaparan materi juga terkait pemberdayaan, pemberdayaan masyarakat merupakan sebuah upaya untuk merubah pola perilaku masyarakat untuk dapat meningkatkan kemampuan dan kemandirian. Tujuan dari pemberdayaan adalah perbaikan kelembagaan, perbaikan usaha, perbaikan pendapatan, perbaikan lingkungan, perbaikan kehidupan dan perbaikan masyarakat. Pemberdayaan dapat dilakukan dengan 4 aspek yaitu pemanfaatan potensi lokal, peningkatan aksestabilitas, peningkatan kapasitas, dan perlindungan sosial. Apabila potensi-potensi lokal yang ada di Desa Jatisari dapat dimanfaatkan, dikembangkan dan dikelola dengan baik maka akan sangat mendukung terciptanya kawasan agrowisata Desa Jatisari. Ma'ruf (2017) menyatakan bahwa urutan prioritas alternatif pilihan penting dalam rangka pembangunan pertanian berkelanjutan diantaranya adalah penguatan kelembagaan petani, pengembangankader petani yang paham pertanian berkelanjutan, sertameningkatkan kegiatan-kegiatan teknologi pertanian. Pemberian materi mengenai Sistem Pertanian Terpadu disajikan pada Gambar 3. 
SPEKTA

Jurnal Pengabdian Kepada Masyarakat : Teknologi dan Aplikasi

Vol. 2, No. 1, Juni 2021

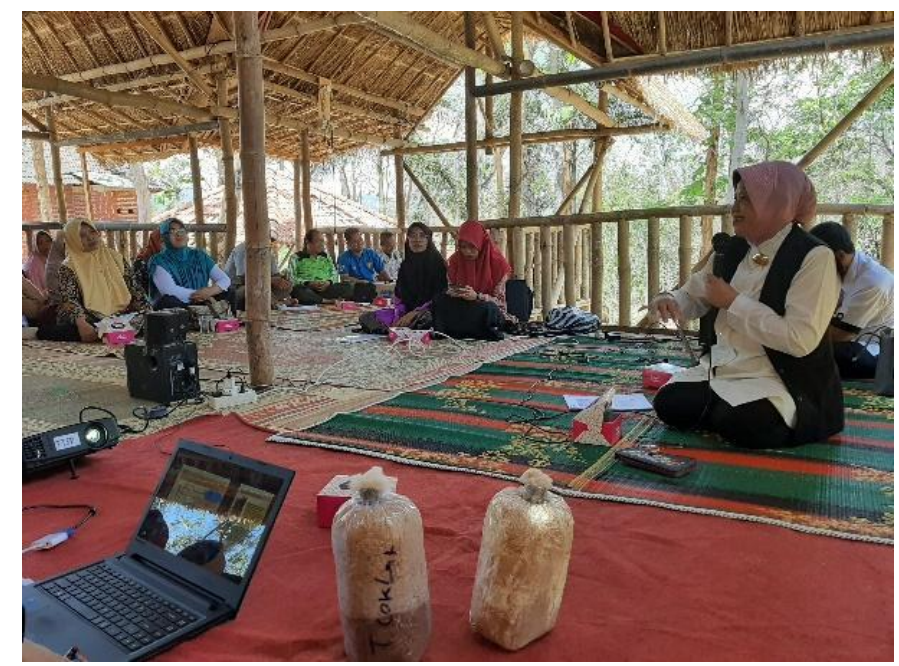

Gambar 3. Pemberian materi mengenai Sistem Pertanian Terpadu

Pemaparan meteri yang kedua adalah Dr. Joko Sutrisno, M.P. mengenai kewirausahaan. Beliau menyampaikan bagaimana tahapan-tahapan dalam memulai kewirausahaan. Kewirausahaan penting untuk mendukung adanya kawasan agrowisata desa Jatisari terutama untuk strategi pengolahan dan pemasaran produk. Potensi sumber daya lokal Desa Jatisari dapat dimanfaatkan menjadi produk dan menjadi sumber pendapatan. Menurut Altieri (1999) bahwa mempertahankan serta meningkatkan produksi yang telah dicapai merupakan pengembangan dalam pembangunan sistem pertanian berkelanjutan yang perlu ditekankan. Simbolon et al (2017) menambahkan bahwaaset produksi yang berupa sumber daya alam butuh dipahami bentuk, keberadaan serta karakternya sehingga pemafaatannya terarah. Para peserta sangat antusias mengikuti dan melakukan diskusi mengenai kewirausahaan. Budiyanto (2020) menyatakan bahwa pemberian penyuluhan mengenai pemasaran dapat menumbuhkan motivasi dalam memasarkan produk. Peserta kegiatan pengabdian dapat dilihat pada Gambar 4.

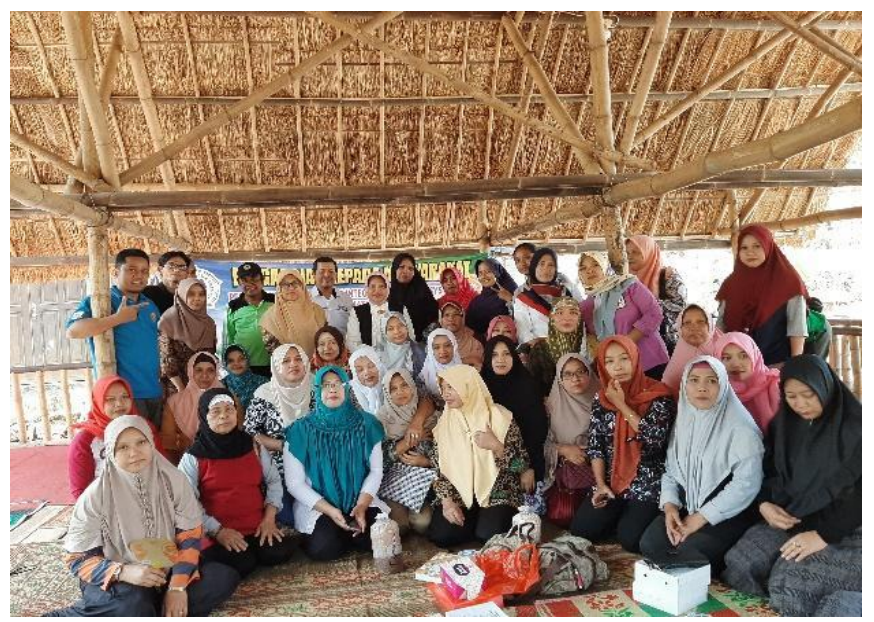

Gambar 4. Peserta kegiatan pengabdian

Perwujudan dari penyuluhan mengenai sistem petanian terpadu dan kewirausaahan mulai diterapkan di Desa Jatisari. Hasil dari pendampingan yang dilakukan antara lain budidaya tanaman porang dan budidaya lele serta usaha kelompok wanita tani berupa telur asin dan bandeng presto. Hal ini membuktikan bahwa sumber daya manusia dan 
Vol. 2, No. 1, Juni 2021

sumber daya alam di Desa Jatisari sangat mendukung dalam perwujudan kawasan agrowisata. Gambar 5 merupakan bentuk dari perwujudan dari system pertanian terpadu yang dikerjakan oleh tim pengabdi.

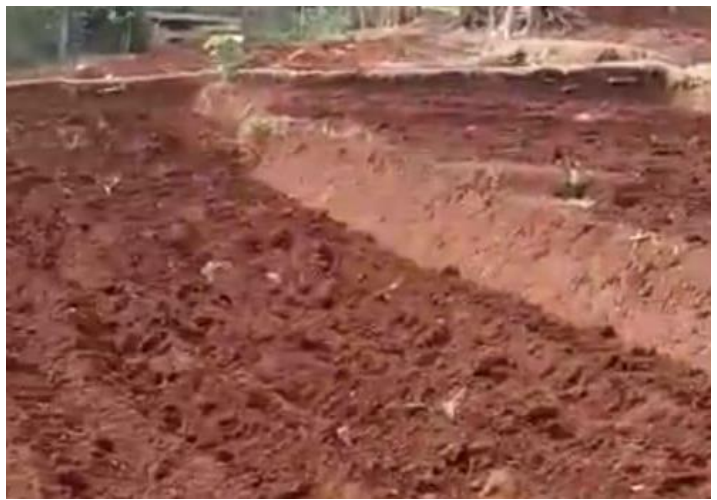

(a) Lahan yang akan digunakan untuk penanaman tanaman

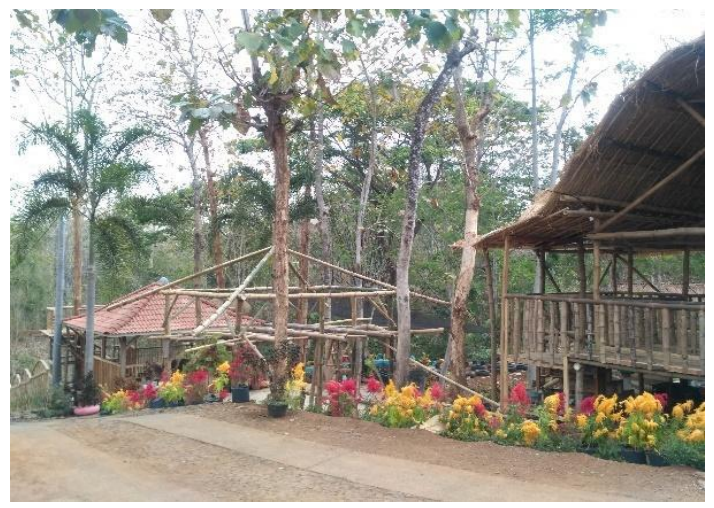

(c) Kondisi calon kawasan Agrowisata Desa Jatisari

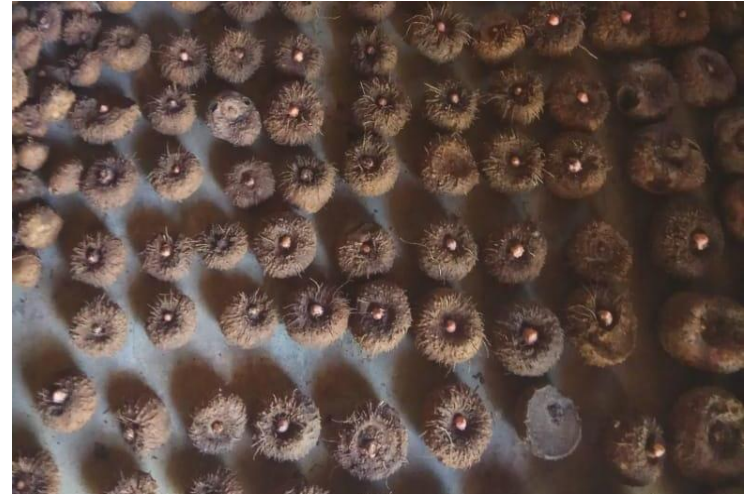

(b) Bubil katak sebagai bibit tanaman porang

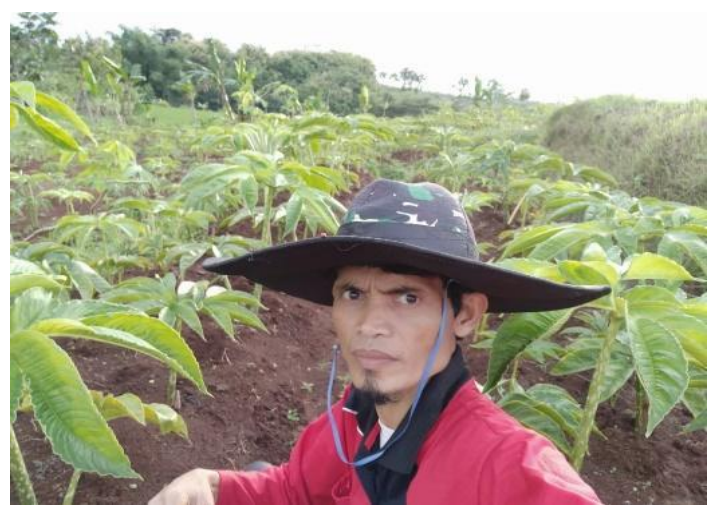

(d) Pak Teguh dengan tanaman porangnya

Gambar 5. Perwujudan dari sistem petanian terpadu

\section{KESIMPULAN}

Desa Jatisari memiliki prospek yang baik dalam pengembangan kawasan agrowisata. Hasil kegiatan pengabdian mampu meningkatkan motivasi dan semangat masyarakat Desa Jatisari dalam mewujudkan kawasan desa agrowisata. Potensi sumber daya lokal yang saat ini dimanfaatkan dan dikembangkan guna mendukung pengembangan kawasan agrowisata antara lain budidaya tanaman porang dan budidaya lele serta usaha kelompok wanita tani berupa telur asin dan bandeng presto.

\section{DAFTAR PUSTAKA}

Abolla, N., Neonufa, N.E.M., Wardhana, L.W., Basri, M. Kajian Pengembangan Sistem Pertanian Terpadu pada Model Usahatani Konservasi Berbasis Teknologi Hedgerow dalam Pengelolaan Agroekosistem Lahan Lering di Dataran Tinggi Netpala, TTS. 23(1). 611-619.

Altieri, M. A. (1999). Applying Agroecology to Enhance the Productivity of Peasant Farming Systems. Environment, Development and Sustainability, 197-217. 
Vol. 2, No. 1, Juni 2021

https://doi.org/10.1023/A

Anam, C., Amiroh, A., \& Aminuddin, M. Imam. (2010). Pemberdayaan Masyarakat Dalam Peningkatan Produktivitas Lahan Pekarangan Melalui Sistem Pertanian Terpadu Berbasis Kearifan Lokal. Seminar Nasional Sistem Informasi, September, 795-808.

Budiyanto, T. (2020). Strategi Pemasaran Usaha Kecil Menengah Pada Ibu-Ibu Aisyiah Muhammadiyah Bali. SPEKTA (Jurnal Pengabdian Kepada Masyarakat: Teknologi Dan Aplikasi), 1(1), 17.

Dwikoranto, C. A., Agus, A., \& Suhartanto, B. (2015). Pengembangan Sistem Pertanian Siklus-Bio Terpadu untuk Peningkatan Produktivitas Ternak Sapi pada Kelompok Ternak Desa Margoagung, Sayegan, Sleman, Yogyakarta. Jurnal Pengabdian Kepada Masyarakat (Indonesian Journal of Community Engagement), 1(1), 96-108. Ittaqillah, E., Sadono, D., \& Wahyuni, E. S. (2020). Hubungan Partisipasi Petani dengan Keberlanjutan Sistem Pertanian Terpadu Mina Padi. Jurnal Sains Komunikasi Dan Pengembangan Masyarakat [JSKPM], 4(1), 55.

Ma'ruf, A. (2017). Agrosilvopastura Sebagai Sistem Pertanian Terencana Menuju Pertanian Berkelanjutan. Bernas, 13(1), 81-90.

Nurcholis, M., \& Supangkat, G. (2011). Pengembangan Integrated Farming System Untuk Pengendalian Alih Fungsi Lahan Pertanian. Prosiding Seminar Nasional |Pengembangan Integrated Farming System, Juli, 71-84.

Rachmawatie, S. J., Widiastuti, L., Sutrisno, J., \& Rahayu, E. S. (2019). Integrated farming system development based on local potential to improve food security and increase the farmers income: Case study in Jatisari Village, Jatisrono Sub-district, Wonogiri Regency. IOP Conference Series: Earth and Environmental Science, 347(1).

Rauf, A., Rahmawaty, \& Said, D. B. T. J. (2013). Sistem Pertanian Terpadu Di Lahan Pekarangan Mendukung Ketahanan Pangan Berkelanjutan Dan Berwawasan Lingkungan. Jurnal Pertanian Tropik, 1(1), 1-8.

Ruhiyat, R., Indrawati, D., Indrawati E., Siami L., Upaya Pemberdayaan Masyarakat dalam Penerapan Sistem Pertanian Terpadu di Kampung Injeman, Desa Cibodas, Kecamatan Pasirjambu, Kabupaten Bandung. Agrokreatif: Jurnal Ilmiah Pengabdian kepada Masyarakat, 6(2): 97-104.

Salli, M. K., Matheus, R., \& Rampoon, M. S. (2019). Kajian Produktivitas dan efisiensi Pemanfaatan Lahan Sistem Pertanian Terpadu pada Agroekosistem Lahan Kering Dataran Rendah desa Fatukanutu Kabupaten Kupang. Partner, Tahun 23 N, 507515.

Simbolon, S. D., Nasution, Z., \& Rauf, A. (2017). Sistem Pertanian Berkelanjutan Pada Lahan Dataran Tinggi di Kawasan Hulu DAS Deli Sumatera Utara. Jurnal Serambi Engineering, 1(2), 85-92.

Siswati, L., \& Nizar, R. (2012). Model Pertanian Terpadu Tanaman Hortikultura dan Ternak Sapi untuk Meningkatkan Pendapatan Petani. Jurnal Peternakan Indonesia (Indonesian Journal of Animal Science), 14(2), 379.

Warintan, S. E., Wahyuni, B., \& Listyorin, F. . (2020). Sistem Pertanian Terpadu Dengan Sistem Kandang Paddock Untuk Meningkatkan Pendapatan. Dinamisia: Jurnal Pengabdian Kepada Masyarakat, 4(1), 133-139. 
SPEKTA

Jurnal Pengabdian Kepada Masyarakat : Teknologi dan Aplikasi

Vol. 2, No. 1, Juni 2021

Halaman ini sengaja dikosongkan

This page is intentionally left blank. 